\title{
The impact of Saharan dust and black carbon on albedo and long-term mass balance of an Alpine glacier
}

\author{
J. Gabbi ${ }^{1}$, M. Huss ${ }^{1,2}$, A. Bauder ${ }^{1}$, F. Cao ${ }^{3,4}$, and M. Schwikowski ${ }^{3}$ \\ ${ }^{1}$ Laboratory of Hydraulics, Hydrology and Glaciology (VAW), ETH Zürich, Zürich, Switzerland \\ ${ }^{2}$ Department of Geosciences, University of Fribourg, Fribourg, Switzerland \\ ${ }^{3}$ Paul Scherrer Institute (PSI), Villigen PSI, Switzerland \\ ${ }^{4}$ Guangzhou Institute of Geochemistry, Chinese Academy of Sciences, Guangzhou, China \\ Correspondence to: J. Gabbi (gabbij@vaw.baug.ethz.ch)
}

Received: 20 January 2015 - Published in The Cryosphere Discuss.: 24 February 2015

Revised: 9 May 2015 - Accepted: 14 June 2015 - Published: 30 July 2015

\begin{abstract}
Light-absorbing impurities in snow and ice control glacier melt as shortwave radiation represents the main component of the surface energy balance. Here, we investigate the long-term effect of snow impurities, i.e., mineral dust and black carbon (BC), on albedo and glacier mass balance. The analysis was performed over the period 1914-2014 for two sites on Claridenfirn, Swiss Alps, where an outstanding 100-year record of seasonal mass balance measurements is available. Information on atmospheric deposition of mineral dust and $\mathrm{BC}$ over the last century was retrieved from two firn/ice cores of high-alpine sites. A combined mass balance and snow/firn layer model was employed to assess the effects of melt and accumulation processes on the impurity concentration at the surface and thus on albedo and glacier mass balance. Compared to pure snow conditions, the presence of Saharan dust and $\mathrm{BC}$ lowered the mean annual albedo by 0.04 0.06 depending on the location on the glacier. Consequently, annual melt was increased by $15-19 \%$, and the mean annual mass balance was reduced by about $280-490 \mathrm{~mm}$ w.e. $\mathrm{BC}$ clearly dominated absorption which is about 3 times higher than that of mineral dust. The upper site has experienced mainly positive mass balances and impurity layers were continuously buried whereas at the lower site, surface albedo was more strongly influenced by re-exposure of dust and $\mathrm{BC}$-enriched layers due to frequent years with negative mass balances.
\end{abstract}

\section{Introduction}

Deposition of mineral dust and $\mathrm{BC}$ have a fundamental impact on the energy balance of glaciers and snow-covered areas by increasing the absorption of solar radiation. Along with the enhanced melting due to the darkening of the snow surface, the growth of snow grains is accelerated, which further reinforces snow melt rates (Painter et al., 2007). While light-absorbing impurities control the snow albedo mainly in the visible wavelengths, the snow grain size affects the albedo in the near-infrared. Shortwave radiation is the dominant energy source for the melting of snow, firn and ice, and consequently the surface albedo has an important influence on the mass budget of glaciers (Oerlemans et al., 2009).

Repeated years with negative glacier mass balances lead to a shift in the equilibrium line to higher elevations and to the re-exposure of dust and BC-enriched firn layers at the surface. Snow impurities are mainly retained at the surface during conditions of melt and surface concentrations might be enhanced by up to 1 order of magnitude resulting in a pronounced melt amplification (Sterle et al., 2013).

Absorptive impurities consist of mineral dust, carbonaceous particles and colored organic matter (Warren, 1984). Advection of dust-loaded air masses from the Saharan desert leads to episodic deposition of large amounts of mineral dust in the Alps. Analyses of firn cores from high-alpine sites, resolving the signal of the continental background aerosols, indicated that long-range transported crustal impurities account for about two-thirds and local impurities for about one-third of the total mineral dust deposited (Wagenbach and 
Geis, 1989). One single Saharan dust deposition event may even supply $30 \%$ of the total annual dust budget at highaltitude mountain glaciers (Schwikowski et al., 1995). Most prominent Saharan dust episodes in the Alpine region occurred in the years 1936-1937, 1977, 1990 and 2000 leaving marked dust horizons in firn/ice cores (Schwikowski et al., 1995; Jenk et al., 2009; Sigl, 2009).

$\mathrm{BC}$ refers to the strongly light-absorbing component of soot and is emitted naturally and anthropogenically by incomplete combustion of fossil fuels and by biomass burning. $\mathrm{BC}$ has become a focus of interest as it has been identified recently as one of the major contributors to global climate change (Ramanathan and Carmichael, 2008; Bond et al., 2013). BC contributes to global warming by absorption of sunlight, firstly when it is suspended in the atmosphere, and secondarily when it is deposited on snow and ice by reducing the albedo and hence accelerating melting. Along with the beginning of the era of industrialization, global BC emissions sharply increased and continued to rise into the 21th century. In the European region, BC concentrations started to decrease in the mid-20th century and have stabilized over the last few decades (Bond et al., 2007).

Recently different studies investigated the impact of lightabsorbing impurities on snow albedo and the melting of snow. Based on a 10-year record of mineral dust and BC concentrations, retrieved from an ice core at Mera Peak, Nepalese Himalaya, Ginot et al. (2014) found that lightabsorbing particulates cause up to $26 \%$ of the total annual surface melting. Another study performed at Mera Peak shows that mineral dust dominates absorption and may reduce the albedo of snow by up to $40 \%$ (Kaspari et al., 2014). Investigations for the Colorado River basin, western US, show that the radiative forcing of mineral dust deposition may shorten the duration of snow cover by several weeks (Skiles et al., 2012) and also affects the timing and magnitude of runoff (Painter et al., 2010). It was suggested that increasing anthropogenic emissions of black carbon during the Industrial Revolution have forced the end of the Little Ice Age in the Alps (Painter et al., 2013).

In this study we assess the significance of natural mineral dust and anthropogenic BC particles in snow and firn on the mass balance of a high-mountain glacier over a centennial period (1914-2014). Using a unique 100-year record of seasonal glacier mass balances, ice core records of past atmospheric deposition of Saharan dust/BC and a sophisticated modeling approach, we examined the contribution of light-absorbing impurities to glacier melt for (1) a site with accumulation conditions over the entire period, where dust is predominately buried by winter snow, and (2) a site at the glacier's equilibrium line involving a re-exposure of buried dust and BC layers at the surface in years with negative mass balance. We have chosen Claridenfirn (Swiss Alps) for which the worldwide longest data series of seasonal glacier mass balance exists. This comprehensive data set enables an accurate and field data-based simulation of ablation and ac- cumulation processes. In order to simulate the feedback between melt, accumulation and snow impurities, a mass balance model was coupled with a snow density model, which tracks the position and the thickness of deposited snow layers and impurities. The mass balance model incorporates an enhanced temperature-index melt model including the shortwave radiation balance and a parameterization for albedo, which is based on the specific surface area of snow and the impurity concentration in the surface snow.

\section{Study site and data}

Claridenfirn is a mountain glacier with an area of approximately $5 \mathrm{~km}^{2}$ and is located on the northern Alpine ridge of the Swiss Alps. The glacier is exposed to the southeast and covered an elevation range of 2540 to 3267 m a.s.l. in 2003 (Fig. 1).

First mass balance measurements date back to 1914 and provide a unique data set covering a period of 100 years. At two different sites, at a lower stake (2680 ma.s.l.) and an upper stake (2890 ma.s.l.), winter, summer and annual mass balance have been measured every year using stakes and snow pits in mid-May and the end of September, respectively. Simultaneously snow density measurements in snow pits have been carried out. The measurements at Claridenfirn are the longest continuous glacier mass balance observations worldwide. More details about the monitoring programme on Claridenfirn are provided by Müller and Kappenberger (1991) and Huss and Bauder (2009).

The forcing of the mass balance model requires daily air temperature and precipitation data for 1914-2014. We used air temperature recorded by the MeteoSwiss weather station Säntis (2490 ma.s.1.), the closest station with long-term records and homogenized time series (Fig. 1, Begert et al., 2005). Monthly air temperature lapse rates were derived by comparison of nearby weather stations to transpose the temperature to the elevation of the study sites. Time series of daily precipitation were taken from a local weather station, Elm (965 ma.s.1.), situated at a distance of $22 \mathrm{~km}$ from Claridenfirn (Fig. 1).

Furthermore, our model requires daily time series of incoming shortwave radiation that were derived from a simple parameterization based on daily temperature ranges (see Sect. 3). Daily maximum and minimum temperature were provided from the MeteoSwiss weather station at Davos over the period 1914-2014 (Fig. 1). For calibrating the parameterization, daily values of incoming solar radiation of 19812014 recorded at the same station were used. In addition, a unique data set of monthly means of global solar radiation for Davos, covering the period 1936-2014, is provided by the Global Energy Balance Archive (GEBA; Ohmura et al., 1989), and was employed to improve the performance of the cloud factor parameterization. 


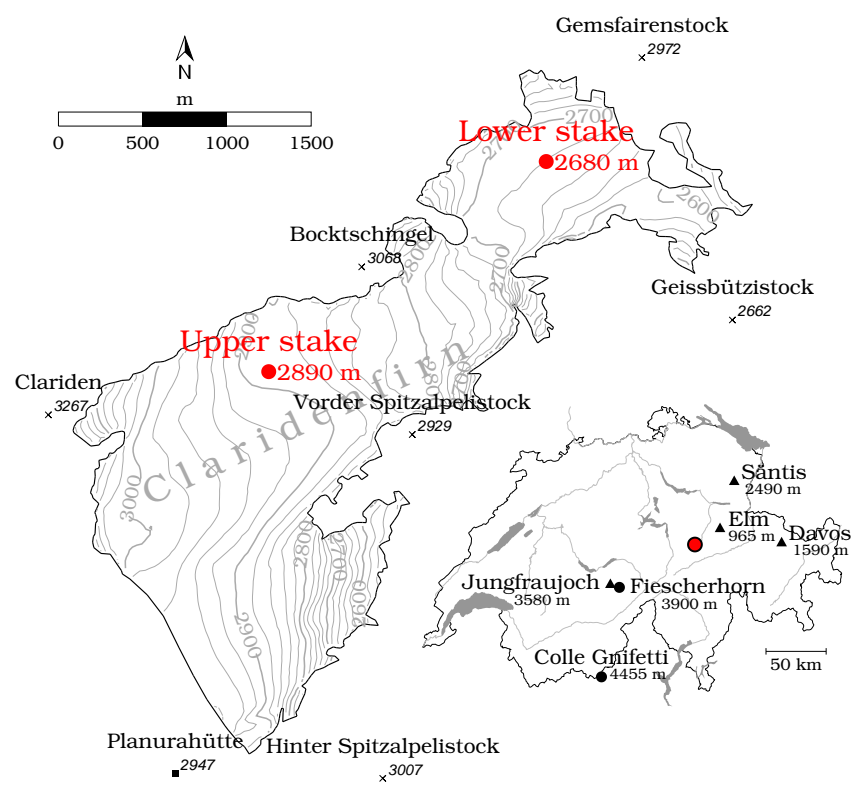

Figure 1. Study site overview. The red dots on Claridenfirn indicate the lower and the upper stake. The inset shows the location of the study site within Switzerland (red point), of the ice core sites Colle Gnifetti and Fiescherhorn (black dot). The aerosol measurement station Jungfraujoch and the weather stations used to derive meteorological time series (black triangles) are indicated.

A firn/ice core from the cold glacier saddle of Colle Gnifetti (4455 ma.s.l., Monte Rosa, Switzerland), retrieved in 2003, provides a continuous record of annual iron (Fe) concentrations over 1914-1997 (Sigl, 2009), which was used to infer the mineral dust concentration in precipitation (Fig. 2a). For the years 1998-2007, which are not covered by the $\mathrm{Fe}$ data, the $\mathrm{Fe}$ concentration was derived from the calcium record, extending the 2003 data set with a shallow core collected at the same site in 2008 (Sigl, 2009), taking advantage of the high correlation between the two dust tracers. Concentrations of BC were obtained from a firn/ice core from Fiescherhorn (3900 m a.s.l., Bernese Alps, Switzerland) drilled in 2002 (Fig. 2a; Jenk et al., 2006). This core provides mean yearly concentrations of elemental carbon (EC) over the period 1914-2002, which can be used as proxy for BC, as $\mathrm{EC}$ and $\mathrm{BC}$ are constituted of the same fraction of carbonaceous particles (Lavanchy et al., 1999). For BC and mineral dust concentrations of the years 2002-2014 and 2007-2014, respectively, which are not covered by the ice core data, a mean concentration averaged over the entire period was assigned (Fig. 2a). Furthermore, daily BC aerosol measurements of Jungfraujoch ( $3580 \mathrm{ma.s.1.}$., Fig. 1) conducted in the frame of the Global Atmosphere Watch (GAW) monitoring programme, covering the period 1995-2000, were used to derive an annual cycle of BC concentrations in the atmosphere.
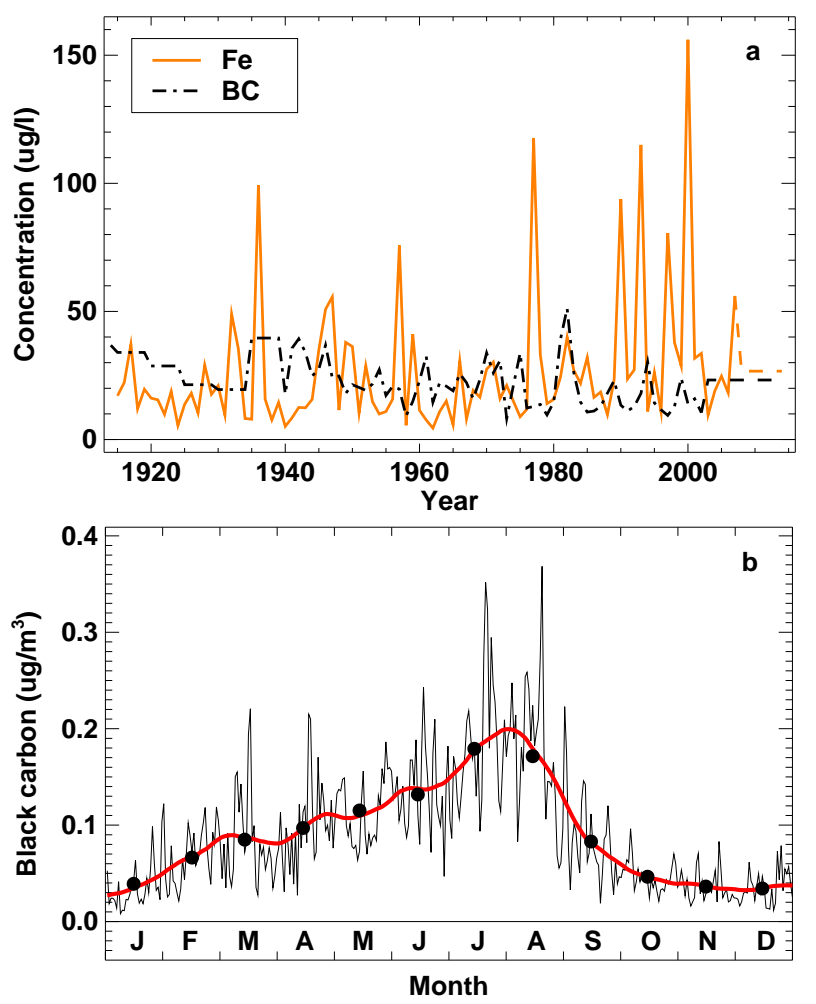

Figure 2. (a) Concentrations of Fe (Sigl, 2009) and BC (inferred from EC; Jenk et al., 2006) over the period 1914-2014 retrieved from the Colle Gnifetti and Fiescherhorn ice core, respectively (Fig. 1). (b) Mean annual cycle of BC concentrations in the atmosphere measured by GAW at Jungfraujoch averaged over the years 1995-2000. Dots refer to the monthly means, and the solid red line refers to the running mean.

\section{Methods}

In order to determine the impact of Saharan dust events on surface albedo and glacier melt, a mass balance model including a parameterization for snow, firn and ice albedo was coupled with a snow/firn density model to track the position and thickness of the snow layers and dust. The physical albedo parameterization is based on the evolution of the specific surface area of snow grains and includes the option to simulate the effect of snow impurities on pure snow albedo. Atmospheric input of mineral dust and BC was derived based on the ice/firn core data. The mass balance model was forced by daily time series of air temperature, precipitation and incoming shortwave radiation and was run over a 100 -year period (1 October 1914 to 30 September 2014). Hereafter, the data series of mineral dust and $\mathrm{BC}$ and the individual components of the employed mass balance and snow density model are described in detail. 


\subsection{Input of mineral dust and black carbon}

\subsubsection{Mineral dust}

The absorption of mineral dust in the visible spectrum is highly sensitive to the content of iron oxides. Kaspari et al. (2014) determined light absorption of mineral dust in snow and ice of a Himalayan glacier based on gravimetrically determined Fe concentrations. Accordingly, we used records of iron $(\mathrm{Fe})$, provided by the ice core, to infer mineral dust concentrations. Iron oxides mainly consist of the minerals goethite and haematite (Sokolik and Toon, 1999; Lafon et al., 2006). Since they have different light absorption spectra (e.g., Lafon et al., 2006) their relative proportion has to be known for calculating the radiative properties of dust. According to Shi et al. (2011) the mass ratio of the mineral haematite to the minerals haematite plus goethite for Saharan dust is 0.42 on average. Based on the assumption that about $45-64 \%$ of the total $\mathrm{Fe}$ is encompassed in lightabsorbing oxides (Lafon et al., 2004), the mass of goethite and haematite is calculated following Kaspari et al. (2014) and used as proxy for the absorption of mineral dust.

Most of the dust peaks can be related to long-range transported crustal impurities, which account for about $70 \%$ of the total deposited mineral dust (Wagenbach et al., 1996). This is a conservative assumption since local dust contains a lower portion of Fe-oxides. We therefore assume that all mineral dust is made up by Saharan dust.

Errors in the annual layer counting of the ice cores might involve uncertainties of $\pm 1-2$ years (Eichler et al., 2000). However, we consider this having a minor impact on mass balance simulations since dates of intense Saharan dust events are well known and smaller events might have a minor effect on average mass balance over a 100 -year period.

The annual amount of mineral dust (i.e., Fe-oxide) was distributed over the year according to the Saharan dust climatology reported by Collaud Coen et al. (2004). They analyzed the number and duration of Saharan dust events per month based on measurements of the aerosol scattering coefficient performed at Jungfraujoch in the years 2001-2002. Higher probability of occurrence was observed in the March-June and the October-November period. Extended time series of the years 2001-2012 confirm this distribution (MeteoSwiss, 2014a). Three different classes of Saharan dust events were defined: Saharan dust events lasting between 4 and $10 \mathrm{~h}$, between 10 and $24 \mathrm{~h}$ and longer than $24 \mathrm{~h}$. The inferred average distribution of the number of events per month and the mean duration of each class were scaled by the annual dust concentrations obtained from the ice core analysis in order to derive daily atmospheric deposition rates of Saharan dust. Days within a month were randomly selected except for extraordinarily large events of the years 1936, 1977, 1990 and 2000 for which the date of deposition is exactly known from literature (SMA-Annalen, 1864-2014; Prodi and Fea, 1979; Schwikowski et al., 1995). We assigned $30 \%$ of the total an- nual dust amount to these extraordinary large events according to Schwikowski et al. (1995).

\subsubsection{Black carbon}

While Saharan dust transport has an episodic character, deposition of BC is controlled by seasonal variations in atmospheric stability, which is higher in winter than in summer. In order to mimic the yearly cycle of BC input, daily ambient $\mathrm{BC}$ measurements at Jungfraujoch, performed in the frame of the GAW monitoring programme, were used. Based on these measurements, daily anomalies averaged over the period 2002-2013 were derived and applied to the annual BC concentrations provided by the firn/ice core in order to infer daily atmospheric deposition rates of BC (Fig. 2b).

\subsubsection{Scaling to study site}

Several studies performed detailed investigations of the regional and altitudinal distribution of major ions in the high Alpine region (e.g., Nickus et al., 1997; Rogora et al., 2006). They found a marked regional variability but no clear trends, neither in distance nor in altitude. Due to a lack of clear indication, we assumed that $\mathrm{Fe} / \mathrm{BC}$ concentrations at Claridenfirn are in a similar range as the concentrations observed on Colle Gnifetti and Fiescherhorn, respectively, and employed measured $\mathrm{Fe} / \mathrm{BC}$ concentrations directly without a transfer function. In order to estimate the influence of potential differences in their input concentration, we performed a sensitivity analysis (see Sect. 5).

\subsection{Mass balance model}

For simulating snow and ice melt, the enhanced temperatureindex (ETI) model (Pellicciotti et al., 2005) was employed. This model computes melt as a function of air temperature and shortwave radiation and accounts for the effects of albedo and cloudiness on melting:

$M=\left\{\begin{array}{ccc}\operatorname{TF} T_{\mathrm{a}}+\operatorname{SRF}(1-\alpha) G & : & T_{\mathrm{a}}>T_{\tau} \\ 0 & : & T_{\mathrm{a}} \leq T_{\tau}\end{array}\right.$,

where $T_{\mathrm{a}}$ is the air temperature, $\mathrm{TF}\left(\mathrm{mmd}^{-1}{ }^{\circ} \mathrm{C}^{-1}\right)$ and SRF $\left(\mathrm{mm} \mathrm{m}^{2} \mathrm{~d}^{-1} \mathrm{~W}^{-1}\right)$ are the tuning parameters, $\alpha$ the surface albedo and $G$ the global incoming shortwave radiation $\left(\mathrm{W} \mathrm{m}^{-2}\right) . T_{\tau}$, the threshold temperature above which melt occurs, is set to $0^{\circ} \mathrm{C}$. $G$ is calculated from a cloud transmissivity factor, cf, and the clear-sky incoming solar radiation, the latter based on the approaches by Iqbal (1983) and Corripio (2003).

Snow accumulation was computed by the station precipitation and a correction factor, $c_{\text {prec }}$, accounting for the elevation difference between the station and the glacier and gauge undercatch. A threshold temperature of $1.5^{\circ} \mathrm{C}$ with a linear transition range of $\pm 1.0^{\circ} \mathrm{C}$ was applied to calculate the occurrence of solid and/or liquid precipitation. 


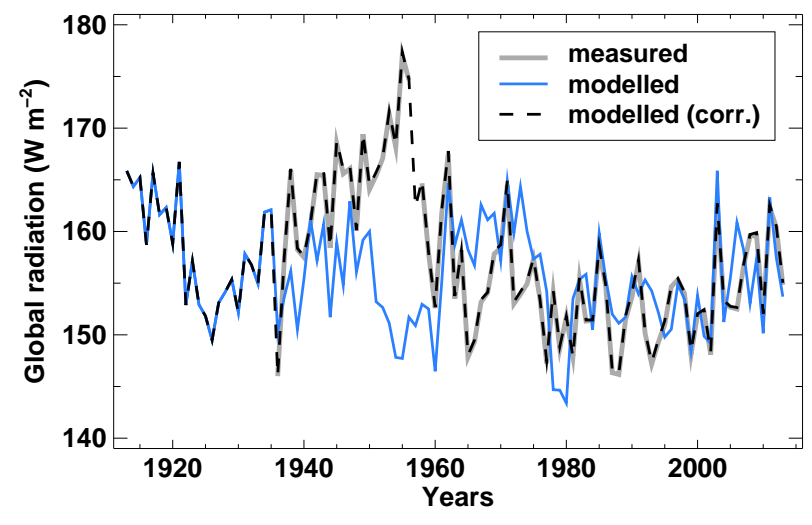

Figure 3. Comparison of mean annual global radiation measured at Davos (bold grey, 1936-2014) and global radiation modeled by the cloud factor parameterization (blue). The dashed black line shows annual averages of modeled daily radiation adjusted by the measurements to fit measured monthly means which are used to force the mass balance model.

\section{Cloud factor parameterization}

The cloud transmissivity factor, cf, accounts for the attenuation of solar radiation by clouds and is derived as a function of daily temperature ranges ( $\Delta T$, Pellicciotti et al., 2011):

$\mathrm{cf}=d_{1} \Delta T+d_{2}$.

The two coefficients, $d_{1}$ and $d_{2}$, were derived by linear regression of the daily air temperature range and the difference between actual and potential clear-sky incoming solar radiation. Using the weather station data from Davos (Fig. 1), parameters were calibrated over the period 19812013. Monthly means of global solar radiation of 1936-2014 allowed verifying the performance of the cloud factor parameterization over decadal periods. Despite the simplicity of the approach, simulated shortwave radiation agreed well with observations (Fig. 3). During the 1940s, when very high incoming solar radiation was recorded, the cloud factor parameterization, however, exhibited difficulties in reproducing the observations. In order to obtain as reliable as possible radiation values in daily resolution, the monthly averages of daily incoming shortwave radiation derived from the cloud factor parameterization were adjusted to match the monthly means measured at Davos for the years with data (i.e., $78 \%$ of the study period, Fig. 3).

\subsection{Albedo model}

Snow albedo was derived according to the physical snow albedo parameterization by Gardner and Sharp (2010) as the sum of pure snow albedo and its change due to impurities. The albedo of ice was kept constant at 0.2 (Pellicciotti et al., 2005). Pure snow albedo, $\alpha_{S S A}$, is calculated as a function of the specific surface area, SSA, of snow as

$\alpha_{\mathrm{SSA}}=1.48-\mathrm{SSA}^{-0.07}$.
Details on the calculation of SSA are given below. The change in pure snow albedo due to loading of light-absorbing impurities is derived according to

$\mathrm{d} \alpha_{\mathrm{C}}=$

$\max \left(0.04-\alpha_{\mathrm{SSA}}, \frac{-C^{0.55}}{0.16+0.6 \mathrm{SSA}^{0.5}+1.8 C^{0.6} \mathrm{SSA}^{-0.25}}\right)$,

where $C$ is the concentration of $\mathrm{BC}$ in $\mathrm{mg} \mathrm{kg}^{-1}$ (Gardner and Sharp, 2010). In order to model the effect of mineral dust on snow albedo, the mineral dust (i.e., Fe oxides) was converted to optically equivalent concentrations of light-absorbing carbon using mass absorption coefficients (MACs) of BC and Fe oxides of 6.8 and $0.56 \mathrm{~m}^{2} \mathrm{~g}^{-1}$, respectively (Alfaro et al., 2004; Kaspari et al., 2014). The direct-beam albedo of the impurity-loaded snow is then obtained as $\alpha=\alpha_{\mathrm{SSA}}+d \alpha_{\mathrm{C}}$. The effect of the solar zenith angle on the albedo is not considered as the model runs on daily basis.

\subsubsection{SSA model}

The specific surface area of the snow grains was calculated relying on the approach by Roy et al. (2013) that considers both dry and wet snow metamorphism. In the case of dry snow conditions, the evolution of SSA is computed according to Taillandier et al. (2007), as a logarithmic function of snow age and snow temperature, $T_{\text {snow }}$, as

$$
\begin{aligned}
\operatorname{SSA}(t)= & {\left[0.629 \cdot \mathrm{SSA}_{\text {initial }}-15.0 \cdot\left(T_{\text {snow }}-11.2\right)\right] } \\
& -\left[0.076 \cdot \mathrm{SSA}_{\text {initial }}-1.76 \cdot\left(T_{\text {snow }}-2.96\right)\right] \\
& \cdot \ln \left\{t+e^{\frac{-0.371 \cdot \mathrm{SA}_{\text {initial }}-15.0 \cdot\left(T_{\text {snow }}-11.2\right)}{0.076 \cdot \mathrm{SSA}_{\text {initial }}-1.76 \cdot\left(T_{\text {snow }}-2.96\right)}}\right\} .
\end{aligned}
$$

The approximation by Brun (1989) is used to simulate the evolution of snow grains under wet conditions with respect to the liquid water content of the snowpack. The growth of the optical radius of snow, $\Delta R_{\mathrm{opt}}\left(\mathrm{mm} \mathrm{d}^{-1}\right)$, is calculated as

$\Delta R_{\mathrm{opt}}=\frac{C_{1}+C_{2} \cdot \theta^{3}}{R_{\mathrm{opt}}^{2} \cdot 4 \pi}$,

where $\quad C_{1}=1.1 \times 10^{-3} \mathrm{~mm}^{3} \mathrm{~d}^{-1} \quad$ and $\quad C_{2}=3.7 \times$ $10^{-5} \mathrm{~mm}^{3} \mathrm{~d}^{-1}$ are empirical coefficients and $\theta$ is the liquid water content in mass percentage. The SSA decrease is more pronounced when $\theta$ increases. If the liquid water content is greater than zero, the model-derived SSA value is converted into its equivalent optical radius, $R_{\text {opt }}$, with

$R_{\text {opt }}=\frac{3}{\rho_{\text {ice }} \cdot \mathrm{SSA}}$,

where $\rho_{\text {ice }}$ is the density of ice. Then, Eq. (6) is applied and $R_{\text {opt }}$ is reconverted to SSA using Eq. (7). The initial SSA was set to $73.0 \mathrm{~m}^{2} \mathrm{~kg}^{-1}$ (Domine et al., 2007). Following Taillandier et al. (2007), a minimal SSA value of $8.0 \mathrm{~m}^{2} \mathrm{~kg}^{-1}$ was used to avoid unrealistically low values. The liquid water content of the snowpack is provided by a snow density model (see below). 


\subsubsection{Snow density model}

A snow densification model is required to determine the position and the thickness of each snow layer. The simple point model by De Michele et al. (2013) for bulk snow density and snow depth was employed and applied to each snow layer. The two-constituent model solves mass balance equations for the dry and liquid mass of the snow pack, as well as momentum balance and rheological equations for the dry part. It results in a system of three differential equations for depth and density of the dry part of the snowpack, and the depth of liquid water. Sublimation and evaporation are not considered. The main characteristics of the model are shortly described in the following. For more detailed information see De Michele et al. (2013).

A simplified energetic description of the snowpack assuming thermal equilibrium between constituents is used. The temperature profile, $T_{\text {snow }}(z)$, is calculated according to Kondo and Yamazaki (1990) as a bilinear function with snow depth, $h_{\mathrm{s}}$ :

$T_{\text {snow }}(z)=\left\{\begin{array}{cll}T_{\mathrm{a}}-a_{\mathrm{t}} \cdot\left(z-h_{\mathrm{s}}\right) & : & h_{\mathrm{s}} \geq z \geq z_{0} \\ 0{ }^{\circ} \mathrm{C} & : & z_{0} \geq z \geq 0 \\ & & \end{array}\right.$

where $z$ is the snow depth, $z_{0}$ the maximum value of $z$ where the snow temperature reaches $0{ }^{\circ} \mathrm{C}$ and $a_{\mathrm{t}} \approx 0.033^{\circ} \mathrm{Cmm}^{-1}$ the temperature gradient in the surface-near layer.

The change in snow depth, $\mathrm{d} h_{\mathrm{s}} / \mathrm{d} t$, is calculated by considering the effects of snow density changes, fresh snow and melt $M$ :

$$
\frac{\mathrm{d} h_{\mathrm{s}}}{\mathrm{d} t}=-\frac{h_{\mathrm{s}}}{\rho_{\mathrm{d}}} \frac{\mathrm{d} \rho_{\mathrm{d}}}{\mathrm{d} t}+\frac{\rho_{\mathrm{f}}}{\rho_{\mathrm{d}}} s-M,
$$

where $\rho_{\mathrm{d}}$ is the density of dry snow, $\rho_{\mathrm{f}}$ the density of fresh snow, and $s$ the snow precipitation rate. The fresh snow density is derived as a sole function of air temperature following Anderson (1976).

The height of liquid water, $h_{\mathrm{w}}$, is controlled by the amount of liquid precipitation, melt and outflow of the snow pack. Water outflow is calculated according to Nomura (1994) and Singh (2001) by a kinematic wave approximation. If the liquid water content, $\theta$, is larger than the residual water content, $\theta_{\mathrm{r}}$, then the outflow $O$ is obtained as $O=c \rho_{\mathrm{w}} \theta h_{\mathrm{w}}^{d}$ with $c$ and $d$ as constants and $\rho_{\mathrm{w}}$ as the density of water. The residual water content is computed as $\theta_{\mathrm{r}}=F_{\mathrm{c}} \rho_{\mathrm{d}} / \rho_{\mathrm{w}}$ with $F_{\mathrm{c}}=0.02$ (Tarboton and Luce, 1996; Kelleners et al., 2009) the mass of water retained per mass of dry snow. The exponent $d$ is set to $d=1.25$ as proposed by Nomura (1994) and the sitespecific coefficient $c$ is assumed to be equal to $1 \mathrm{~m}^{-1} \mathrm{~h}^{-(d-1)}$ (De Michele et al., 2013). The change in liquid water height, $\mathrm{d} h_{\mathrm{w}} / \mathrm{d} t$, is calculated with

$$
\frac{\mathrm{d} h_{\mathrm{w}}}{\mathrm{d} t}=p+\frac{\rho_{\mathrm{d}}}{\rho_{\mathrm{w}}} M-c \theta h_{\mathrm{w}}^{\mathrm{d}},
$$

where $p$ is the liquid precipitation rate.

The momentum balance equation, $\sigma-\rho_{\mathrm{d}} g h_{\mathrm{s}}$, and the rheological equation, $\eta=\sigma / \dot{\epsilon}$, are used to infer snow density changes, where $\sigma$ is the vertical stress, $g$ the gravitational acceleration, $\dot{\epsilon}$ the vertical strain rate, and $\eta$ the coefficient of viscosity computed as an exponential function of snow density and snow temperature. Accordingly, snow density changes are calculated as

$\frac{\mathrm{d} \rho_{\mathrm{d}}}{\mathrm{d} t}=c_{1} h_{\mathrm{s}} \rho_{\mathrm{d}}^{2} e^{\left(k_{1}\left(T_{\mathrm{snow}}-T_{\tau}\right)-k_{0} \rho_{\mathrm{d}}\right)}$,

where $c_{1}, k_{1}$ and $k_{0}$ are constants set to $0.001 \mathrm{~m}^{2} \mathrm{~h}^{-2} \mathrm{~kg}^{-1}$, $0.08^{\circ} \mathrm{C}^{-1}$ and $0.021 \mathrm{~m}^{3} \mathrm{~kg}^{-1}$, respectively (Kongoli and Bland, 2000; Ohara and Kavvas, 2006; Zhang et al., 2008). Equation (11) describes the change in density due to compaction and temperature change, and is calculated as an exponential function of snow density and snow temperature following Kojima (1967) and Mellor (1975).

\subsubsection{Snow layer model}

Each precipitation event was considered as a single snow layer which is stacked atop of the snow pack. Snow layers with a thickness of less than $1 \mathrm{~cm}$ were merged with the underlying layer in order to reduce computational efforts and to avoid arithmetic errors. If snow density exceeded the pore close-off density $\left(830 \mathrm{~kg} \mathrm{~m}^{-3}\right)$, snow was treated as ice, and the corresponding snow layers were removed from the system.

\subsection{Snow impurity model}

Mineral dust and BC entered the system by liquid or solid precipitation, as wet deposition is expected to be the predominant mechanism (Raes et al., 2000; Koch, 2001). Particulate impurities were supposed to be evenly distributed in precipitation and consequently also in the snow layers. Particulates remained in the corresponding snow layer as long as there was no melt. When melt occurred, impurities of the melted snow were accumulated in the top $2 \mathrm{~cm}$ of the remaining snow layers (e.g., Flanner et al., 2007). When a snow fall event occurred, the dust and BC-enriched top layer became an independent snow layer and was buried by fresh snow. We assumed constant ice albedo and no dust reservoir for ice since the effects of snow impurities on the ice albedo and the removal of snow impurities by melt water on ice are only poorly understood and subject to a high spatial variability. Hence, when firn turned into ice, the dust and BC of the corresponding layer was removed from the system.

Melt water percolation may lead to vertical redistribution of snow impurities. Different studies have investigated the removal of particulate impurities by melt water (e.g., Conway et al., 1996; Flanner et al., 2007). They found that larger particles $(>5 \mu \mathrm{m})$ remain mostly in the snow and are not efficiently removed by percolation of melt water (Conway 


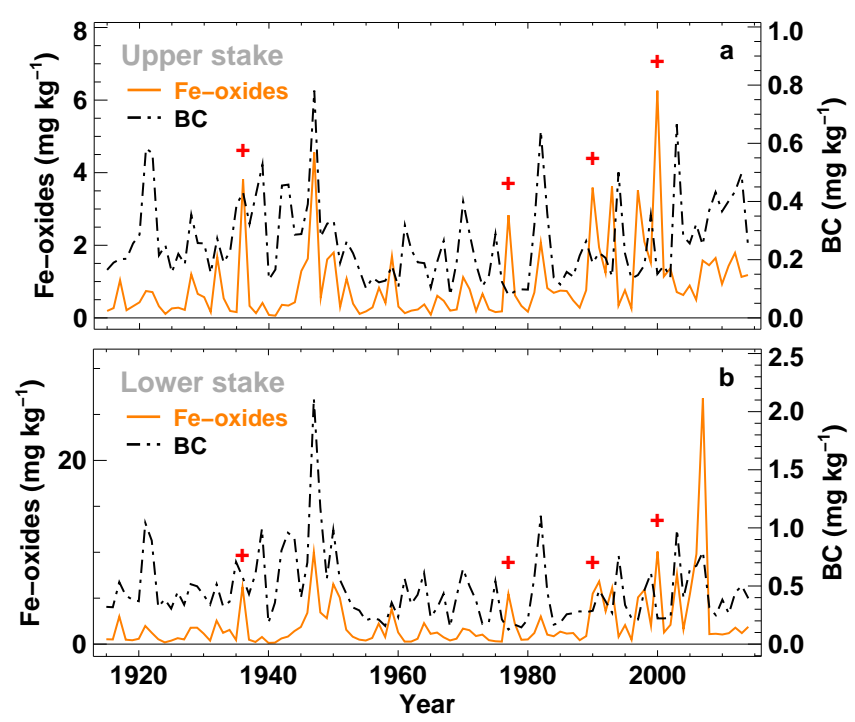

Figure 4. Average Fe-oxide and $\mathrm{BC}$ concentrations in the surface snow at the upper and lower measurement site on Claridenfirn for the period 1914-2014. The crosses mark years with exceptionally high Saharan dust activity. Note that the scales for upper and lower stake are different.

et al., 1996), whereas smaller snow impurities $(\sim 0.2 \mu \mathrm{m})$ are washed out by about $10-30 \%$ per mass of melt (Doherty et al., 2013). According to these results, we assumed that mineral dust (particle size $2.5-4.5 \mu \mathrm{m}$ ) is not affected by wash-out due to melt water, whereas for BC (particle size $0.2-0.3 \mu \mathrm{m}$ ) a removal efficiency (the amount of BC which is removed by melt water with each increment of melt) of $20 \%$ was assumed (Flanner et al., 2007).

\subsection{Calibration}

The melt parameters, TF and SRF, and the accumulation parameter, $c_{\text {prec }}$, were calibrated for each year individually by means of the seasonal balance measurements. This annual calibration ensures that simulated mass balances coincide with observations in order to extract an accurate sequence of melt and accumulation events controlling the surface concentration of light-absorbing impurities. In a first step, $c_{\text {prec }}$ was adjusted according to the measured winter accumulation, then TF and SRF were tuned to the annual mass balance records. This procedure is repeated until the difference between simulated and observed mass balance was less than $10 \mathrm{~mm}$ water equivalent (w.e.). The ratio between $\mathrm{TF}$ and SRF was kept constant over the entire period in order to reduce the degrees of freedom and to avoid changes in air temperature/radiation sensitivity of the model among individual years. The ratio was set to 0.04 according to extensive testing for another Alpine glacier (Gabbi et al., 2014). During calibration the complete snow impurity and snow density model was used.

\section{Results}

\subsection{Snow impurity concentration}

\subsubsection{Saharan dust}

At the upper measurement site, located in the accumulation area of Claridenfirn, the mean annual Fe-oxide concentration in the surface layer was $0.92 \pm 1.04 \mathrm{mg} \mathrm{kg}^{-1}$ on average. Exceptionally high surface loads were observed in years with increased deposition of Saharan dust, particularly in 1936, 1977, 1990 and 2000 (Fig. 4a). Annual Fe-oxide concentrations of up to $6.3 \mathrm{mg} \mathrm{kg}^{-1}$ occurred at the upper stake. Concentrations of similar magnitude as in years with high Saharan dust input were reached in the late 1940s. Periods of intense solar radiation, such as in the 1940s, led on the one hand to increased melting due to higher transmissivity of the atmosphere (Huss et al., 2009) and on the other hand to an enhanced re-exposure of snow impurities, and thus to a distinct darkening of the glacier surface which further reinforced ablation.

At the lower measurement site, located near the glacier's equilibrium line altitude (ELA), the mean Fe-oxide concentration was more than twice as high as at the upper stake and was $2.24 \pm 3.33 \mathrm{mg} \mathrm{kg}^{-1}$ on average. Consistent with the upper site, increased mineral dust amounts were observed during years with high Saharan dust activity and during periods with intense melting (Fig. 4b). In addition to the 1940s, a second period with pronounced accumulation of mineral dust due to enhanced melting occurred in the 2000s. In 2007, the mean Fe-oxide concentration reached a maximum value of $26.8 \mathrm{mg} \mathrm{kg}^{-1}$ as a result of the almost complete melting of the firn layers, and thus the re-exposure of heavily dustloaded layers (e.g., extraordinarily large Saharan dust events of 2000). From 2008 onwards, surface Fe-oxide concentrations at the lower stake declined sharply as all firn layers have been depleted and the bare ice surface was exposed. Thus, due to the prescribed constant ice albedo, the remaining dust did not have an influence on albedo and was assumed to be washed out at the impermeable ice surface.

In the accumulation area (upper stake) most of the mineral dust exposed at the surface originated from deposition occurring during the same year. Only in the few years with negative mass balances mineral dust of previous years reappeared and reinforced the darkening of the glacier surface. In specific years (e.g., 1947 and 1991), mineral dust of previous years accounted for $45-65 \%$ of the total mineral dust at the surface (Fig. 5a). On average, however, the fraction of mineral dust of preceding years becoming albedo relevant was small and made up only $8 \%$ of the total surface dust budget. At the ELA (lower stake) mineral dust of previous years more effectively influenced surface dust concentrations and accounted for about $30 \%$ of the total exposed mineral dust. Particularly in the 1940s and 2000s, but also in the early 1960s and the 1990s, large quantities of previously buried 

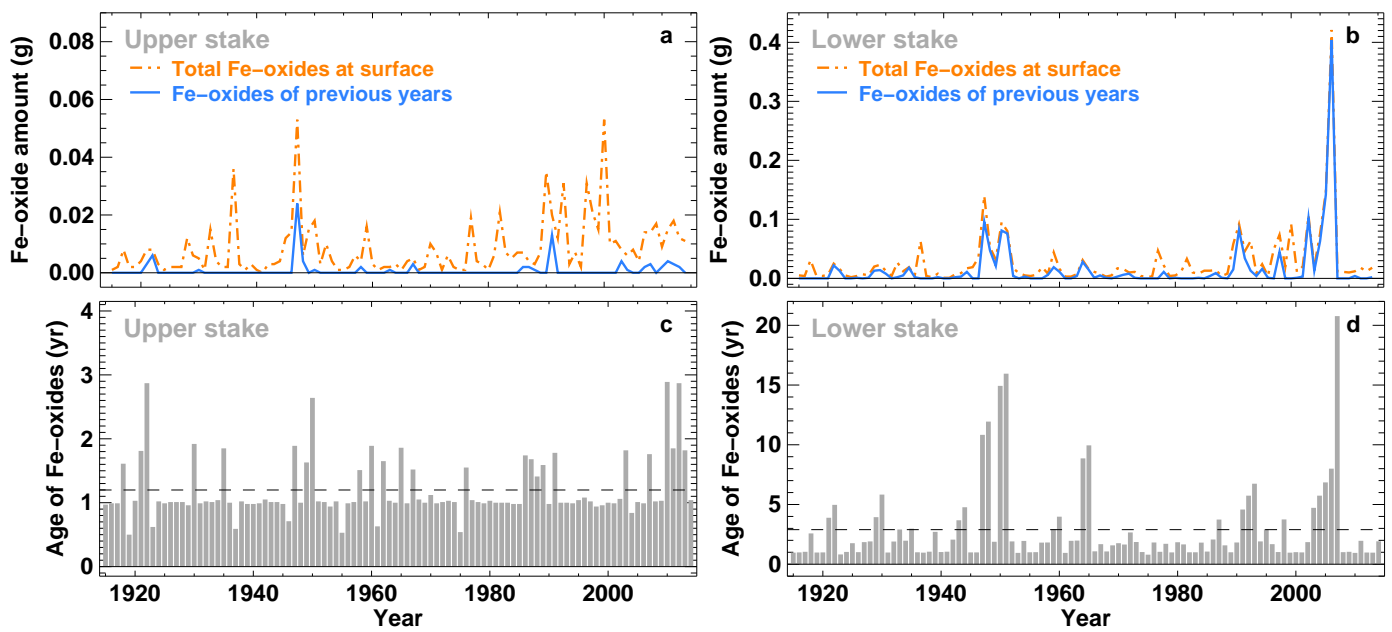

Figure 5. Total Fe-oxide amount of the surface snow layer of each year and the amount of Fe-oxides of previous years emerging at the surface through melt-out over the period 1914-2014 for (a) the upper and (b) the lower stake. (c) and (d) illustrate the age of the oldest mineral dust present at the glacier surface for each year for both sites. Note that the scales for the upper and lower site are different.

dust were re-exposed at the surface. Up to $97 \%$ of the total surface dust in 2006 and 2007 originated from deposition in preceding years (Fig. 5b). Accordingly, mineral dust of much older layers was re-exposed at the surface of the lower measurement site in comparison to the upper stake. While at the stake in the accumulation area, surface dust had a maximum age of 3 years, mineral dust at the lower stake was found to have an age of up to 21 years (Fig. 5c, d).

\subsubsection{Black carbon}

Mean surface concentrations of BC showed a distinctly different pattern than mineral dust concentrations. $\mathrm{BC}$ concentrations at the glacier surface were mainly controlled by the melt regime and were less influenced by episodic deposition compared to Saharan dust (Fig. 4). An exception was the year 1982, when exceptionally high deposition of BC were recorded (see Fig. 2a). Mean concentrations of BC over the entire period were $0.26 \pm 0.14$ and $0.46 \pm 0.29 \mathrm{mg} \mathrm{kg}^{-1}$ on average for the upper and lower stake, respectively. For both locations, highest $\mathrm{BC}$ concentrations were observed in the melt-intense years around 1947 and the deposition-intense year 1982 (Fig. 4). BC concentrations of up to $0.78 \mathrm{mg} \mathrm{kg}^{-1}$ (upper stake) and $2.12 \mathrm{mg} \mathrm{kg}^{-1}$ (lower stake) were found.

\subsubsection{Absorption of mineral dust vs. black carbon}

In contrast to $\mathrm{BC}$, mineral dust concentrations at the surface were up to 5 times larger. However, as BC is much more absorptive than mineral dust (mass absorption coefficient about 10 times higher), the overall absorption by $\mathrm{BC}$ and dust are in a similar range. In individual years with extraordinarily high Saharan dust input, such as in 1936, 1977, 1990 and 2000 , mineral dust dominated the absorption of solar radiation (Fig. 6). In all other years, the absorption of $\mathrm{BC}$ out- weighed the absorption of mineral dust and over the entire period $\mathrm{BC}$ was clearly the dominant absorber. While at the upper stake, the absorption due to $\mathrm{BC}$ was 3.3 times higher on average compared to mineral dust, at the lower stake BC resulted in a 2.2 times higher absorption. These statements are based on the assumption that BC is more efficiently removed by melt water than mineral dust and therefore depend on the chosen removal efficiency. If removal rates of $\mathrm{BC}$ and mineral dust would be in a similar range, the influence of $\mathrm{BC}$ on the absorption would be even larger.

\subsection{Effect of Saharan dust and black carbon on albedo and mass balance}

\subsubsection{Surface albedo}

On average the reduction of mean annual surface albedo due to Saharan dust was less than 0.01 compared to snow with $\mathrm{BC}$ only. At the upper measurement site the mean annual albedo was reduced by $0.004 \pm 0.004$, at the lower stake by $0.008 \pm 0.009$. Regarding summer albedo (April-September), i.e., the albedo during the period with snow, firn and ice melting, the effect of Saharan dust was larger and reduced the mean summer albedo at the upper stake and lower stake by $0.006 \pm 0.006$ and $0.011 \pm 0.012$, respectively. However, in individual years with a high accumulation of Saharan dust (i.e., years with a high Saharan dust input and/or melt-intense periods) the impact on snow albedo was significantly larger. At the lower measurement site, at the transition between accumulation and ablation zone, the largest reduction in albedo occurred in 2007, when the mean annual albedo was reduced by about 0.060 . At the upper stake, highest influence of Saharan dust on the surface albedo was observed in the dustintense year 2000 with a maximal albedo reduction of 0.025 . 

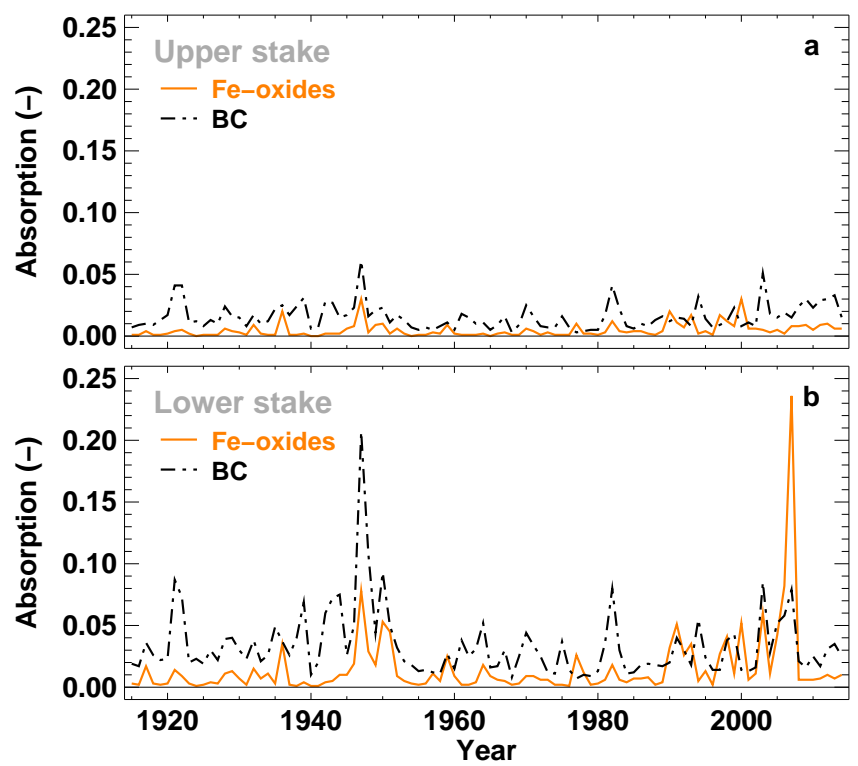

Figure 6. Mean annual absorption (optical depth) of mineral dust and BC over the period 1914-2014 for (a) the upper and (b) the lower stake. The optical depth is calculated as product of mass absorption coefficient of $\mathrm{BC} / \mathrm{Fe}$ oxides and the corresponding loading in the snow surface layer (top $2 \mathrm{~cm}$ ).

The overall impact of BC on the surface albedo was substantially higher than that of Saharan dust. Our results suggest that BC reduced the albedo over 1914-2014 by $0.027 \pm$ 0.009 at the upper stake and by $0.038 \pm 0.013$ at the lower stake compared to snow with dust only. The largest contribution of $\mathrm{BC}$ to albedo reduction occurred in the melt dominated periods in the 1940s and the 2000s, when the albedo was lowered by up to 0.06. In total, Saharan dust and black carbon reduced the mean annual albedo by 0.041 and 0.062 on average compared to pure snow at the upper and lower stake.

\subsubsection{Mass balance}

The impact of Saharan dust on the total mass change over the 100-year period was in the order of a few meters and was less pronounced in the accumulation area than at the ELA (Fig. 7). At the upper measurement site, the difference in total cumulative mass balance due to Saharan dust was $2.8 \mathrm{~m}$ w.e. compared to the measured total 100 -year cumulative mass balance of $125.8 \mathrm{mw}$.e. At the lower stake, the absolute difference was twice as large and was $5.8 \mathrm{mw}$.e. (with a total cumulative mass balance of $26.4 \mathrm{~m}$ w.e.). Regarding annual balance, Saharan dust thus accounted for about $-28 \mathrm{mmw}$.e. $\mathrm{yr}^{-1}$ at the upper stake and for about $-58 \mathrm{~mm}$ w.e. $\mathrm{yr}^{-1}$ at the lower stake compared to snow with BC only (Fig. 8a and c). Mean annual melt was increased by about $1.4 \%$ (upper stake) and $2.0 \%$ (lower stake) by the
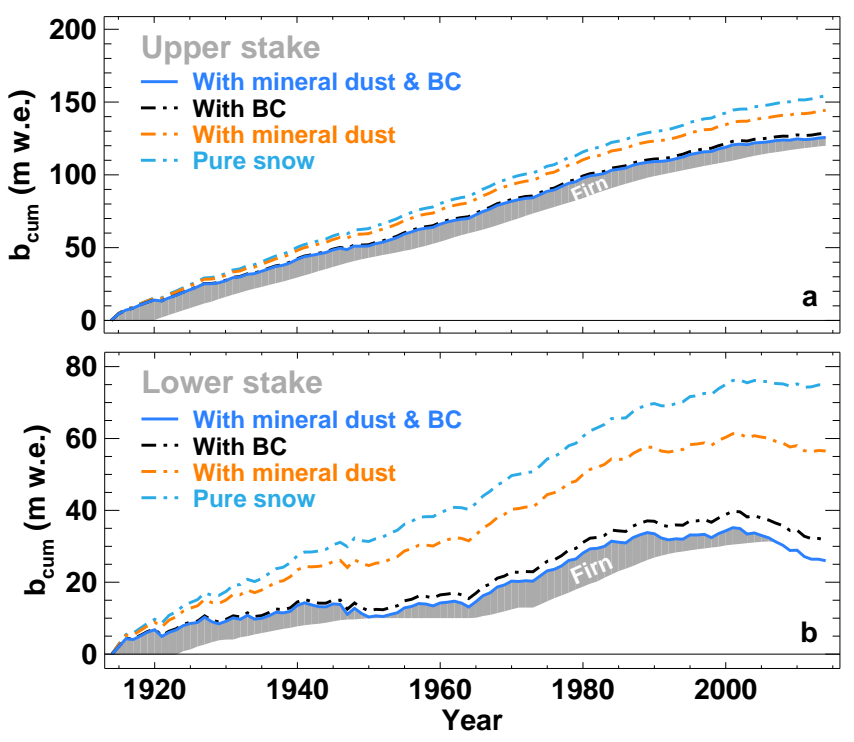

Figure 7. Cumulative mass balance over the period 1914-2014 at (a) the upper and (b) the lower measurement site. The solid blue line refers to the cumulative mass balance under real conditions (including Saharan dust and BC) and is consistent with the direct observations on Claridenfirn. The dash-dotted lines correspond to simulations (1) without Saharan dust (with BC), (2) without BC (but with Saharan dust), and (3) with pure snow conditions. The grey shaded area indicates the thickness of the entire firn column in $\mathrm{m}$ w.e.

presence of Saharan dust. In specific years, Saharan dust enhanced the overall annual melt by up to $13 \%$.

Maximum deviations in annual mass balance due to Saharan dust were up to $-142 \mathrm{~mm}$ w.e. $\mathrm{yr}^{-1}$ for the upper and $-271 \mathrm{~mm}$ w.e. $\mathrm{yr}^{-1}$ for the lower measurement site in individual years. In years with high dust concentrations at the surface (Fig. 4) also largest changes in mass balance were observed (Fig. 8a and c). However, changes in mass balance cannot be directly deduced from average dust concentrations, because (1) the impurity concentration and albedo changes are not linearly related; thus a higher impurity concentration might lead to smaller changes in albedo, and (2) during years with high melt rates other particulate impurities accumulate at the surface, which limits the total impact of Saharan dust on surface mass balance. Thus, despite the exceptionally high surface concentration in 2007, the change in mass balance is only slightly larger than in years with lower surface concentrations as for example in the deposition intense year 2000 (Fig. 8a and c).

The BC-induced albedo changes led to an average reduction in annual mass balance of $183 \mathrm{~mm}$ w.e. $\mathrm{yr}^{-1}$ at the upper and of $301 \mathrm{~mm}$ w.e. $\mathrm{yr}^{-1}$ at the lower stake compared to snow with dust only. In individual years, annual mass balance anomalies might reach up to $-494 \mathrm{~mm}$ w.e. $\mathrm{yr}^{-1}$ at the upper stake and up to $-754 \mathrm{~mm}$ w.e. $\mathrm{yr}^{-1}$ at the lower stake (Fig. $8 \mathrm{~b}$ and d) and peak values up to 3 times larger compared to the effect of Saharan dust. The difference in cumulative mass 

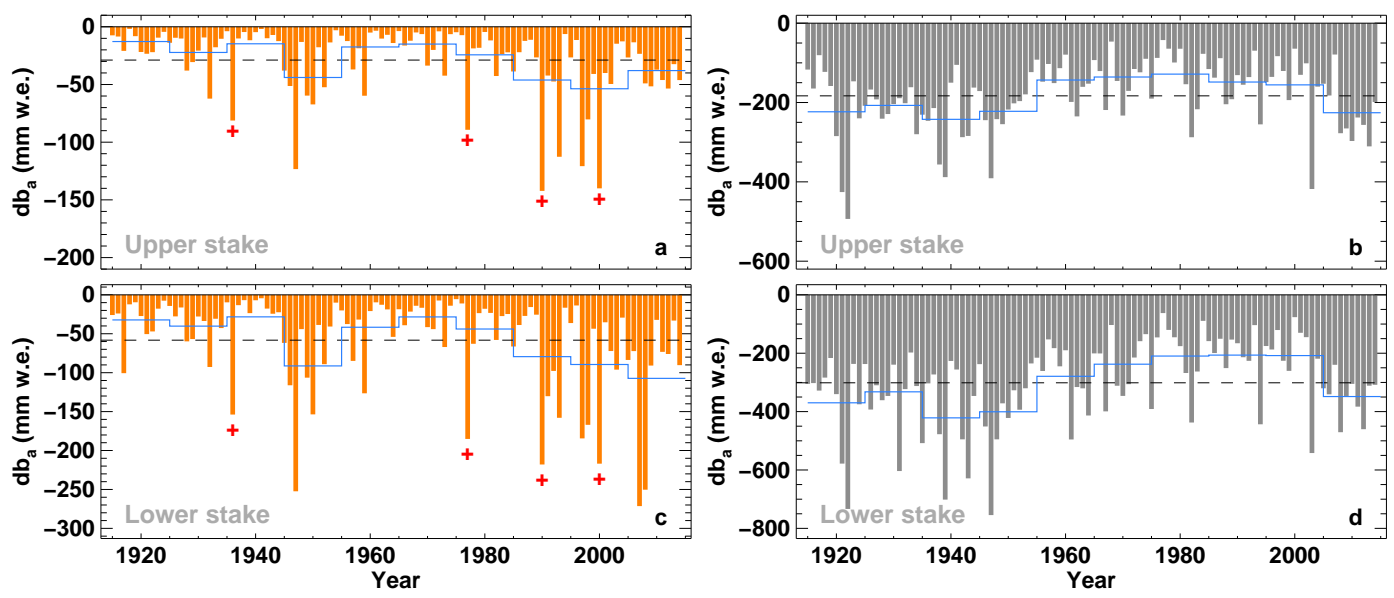

Figure 8. Effect of Saharan dust on annual mass balance for the period 1914-2014 for (a) the upper and (c) the lower stake and the effect of BC for (b) the upper and (d) the lower stake. Bars show differences in annual mass balance between model results including or neglecting Saharan dust/BC. The dashed line refers the mean over the period 1914-2014 and the solid blue line to the 10-year average. Crosses mark years with exceptionally high Saharan dust activity.

balance between the real situation, being consistent with direct field observations (including mineral dust and $\mathrm{BC}$ in the model), and simulations without BC (but with mineral dust) over 1914-2014 is $18.3 \mathrm{~m}$ w.e. for the upper and $30.1 \mathrm{mw}$ w.e. for the lower stake (Fig. 7). Annual melt rates were amplified by $9 \%(11 \%)$ at the upper (lower) stake on average and by $19 \%(22 \%)$ at maximum.

The combined effect of Saharan dust and BC reduced the mean annual mass balance by $282 \mathrm{mmw}$.e. $\mathrm{yr}^{-1}$ and $485 \mathrm{~mm}$ w.e. $\mathrm{yr}^{-1}$ at the upper and lower stake, respectively. Annual melt was amplified by $15 \%$ (upper stake) and $19 \%$ (lower stake) on average by the presence of two lightabsorbing impurities. In the year 1947, characterized by exceptionally high melt rates, Saharan dust and BC intensified annual melt by up to $36 \%$.

\section{Discussion}

\subsection{Radiative forcing}

Converting changes in annual mass balance caused by absorption of dust/BC into the energy consumed for melt allowed calculating the radiative forcing of snow impurities. The radiative forcing $\left(\mathrm{RF}, \mathrm{W} \mathrm{m}^{-2}\right.$ ) was calculated based on the change in melt rate, $\Delta M\left(\mathrm{~m} \mathrm{~s}^{-1}\right)$, caused by the presence/absence of mineral dust and/or BC in snow:

$\mathrm{RF}=\Delta Q_{\mathrm{M}}=\Delta M L_{\mathrm{f}} \rho_{\mathrm{W}}$,

where $Q_{\mathrm{M}}\left(\mathrm{W} \mathrm{m}^{-2}\right)$ is the energy consumed by melt, $L_{\mathrm{f}}\left(333700 \mathrm{~J} \mathrm{~kg}^{-1}\right)$ the latent heat of fusion and $\rho_{\mathrm{W}}$ $\left(1000 \mathrm{~kg} \mathrm{~m}^{-3}\right)$ the density of water. Changes in melt rates are equal to changes in mass balance as presented in Sect. 4.2.2.

For the measurement site in the accumulation area we found a mean radiative forcing over the 100 -year period of
$+0.3 \mathrm{~W} \mathrm{~m}^{-2}$ due to Saharan dust, whereas at the stake close to the equilibrium line the radiative forcing was $+0.6 \mathrm{~W} \mathrm{~m}^{-2}$. In contrast to Saharan dust, the radiative forcing of $\mathrm{BC}$ over 1914-2014 was about 7 times larger, and was +1.9 and $+3.2 \mathrm{~W} \mathrm{~m}^{-2}$ on average for the two sites. In the summer months, July and August, when melting is strongest, the radiative forcing for $\mathrm{BC}$ reached values of $8.7-9.7 \mathrm{~W} \mathrm{~m}^{-2}$ and for Saharan dust of 3.0-3.7 $\mathrm{W} \mathrm{m}^{-2}$, compared to pure snow at the upper stake, and $12.9-15.9$ and $4.7-6.3 \mathrm{~W} \mathrm{~m}^{-2}$ at the lower stake, respectively. At the daily scale, maximum modeled radiative forcing was $15-42 \mathrm{~W} \mathrm{~m}^{-2}$ for Saharan dust and $43-66 \mathrm{~W} \mathrm{~m}^{-2}$ for BC.

At a global scale, the mean radiative forcing from $\mathrm{BC}$ in snow is reported to be in the range of $0.02-0.08 \mathrm{~W} \mathrm{~m}^{-2}$ (Bond et al., 2013; IPCC, 2013). During boreal spring, when the snow-albedo feedback is maximal, the radiative forcing of mineral dust and BC over Eurasia is higher and amounts to 1.2 and $2.7 \mathrm{~W} \mathrm{~m}^{-2}$, respectively (Flanner et al., 2009). For snow-covered surfaces of the Tibetan Plateau the radiative forcing of $\mathrm{BC}$ reaches values of up to $5-25 \mathrm{~W} \mathrm{~m}^{-2}$ in springtime (Flanner et al., 2007; Kopacz et al., 2011; Qian et al., 2011). Similar peak values are found for desert dust in the mountain snow cover of the Colorado River Basin (25$50 \mathrm{~W} \mathrm{~m}^{-2}$, Painter et al., 2007; Skiles et al., 2012). In general, radiative forcing of $\mathrm{BC}$ found for Claridenfirn is at the lower end of the range of values obtained for the Colorado River Basin or Tibetan Plateau. Regarding mineral dust, the effect is also clearly stronger in the western US than in the Alps. In terms of maximum daily radiative forcing, values obtained for Claridenfirn are of similar magnitude as for other regions. However, radiative forcing reported in other studies is not directly comparable to the results of this study as dust/BC source, and the temporal dynamics of melting are different. Furthermore, radiative forcing of some of the 
above-mentioned studies was calculated by directly accounting for the change in the energy fluxes, rather than using the change in melt rates due to light-absorbing impurities as in our approach. Hence, the radiative forcing reported here represents a lower limit as the radiative impact in the pre-melt season is not taken into account.

Painter et al. (2013) suggested that the rapid retreat of Alpine glaciers at the end of the Little Ice Age was forced by increasing $\mathrm{BC}$ concentration due to industrialization. They found BC-induced mass balance anomalies in the order of $-500 \mathrm{~mm}$ w.e. $\mathrm{yr}^{-1}$ for the ablation area, which is similar to our results for the accumulation area $\left(-180\right.$ to $-300 \mathrm{~mm}$ w.e. $\left.\mathrm{yr}^{-1}\right)$ despite the different modeling approaches. While Painter et al. (2013) used a sophisticated radiation model (SNICAR, Flanner et al., 2007) to derive BC radiative forcing and in turn equivalent changes in air temperature and mass balance, we used a simple broadband albedo parameterization in combination with a mass balance model. However, Painter et al. (2013) assume 10-20 times higher $\mathrm{BC}$ concentrations than reported by the ice core data in order account for altitudinal differences between the high-altitude ice core sites and the ablation area. In our study, we do not alter atmospheric deposition rates (see Sect. 5.4), but, contrary to Painter et al. (2013), account for changes in the BC surface concentration due to melt and accumulation processes as well as to removal by melt water. As a result, we obtain similar BC concentrations in the surface layer on average, and thus, a comparable impact of $\mathrm{BC}$ on glacier mass balance. The general agreement of our assessment with that of Painter et al. (2007) indicates the highly relevant role of BC in shaping changes in glacier mass balance over the last century.

\subsection{Sensitivity analysis}

In order to assess the sensitivity of the model results to the chosen input parameters, we performed a sensitivity analysis. Four parameters of the snow impurity model were examined: (1) removal rates of BC by melt water, (2) fraction of $\mathrm{Fe}$ which is presented as $\mathrm{Fe}$-oxides, (3) the proportion of haematite and goethite in the Fe-oxides, and (4) the ratio of the MAC of BC vs. MAC of Fe-oxides. In addition, another four parameters of the SSA model $\left(\mathrm{SSA}_{\mathrm{ini}}, \mathrm{SSA}_{\min }\right.$, $\left.C_{1}, C_{2}\right)$ and six parameters of the snow density model $\left(a_{\mathrm{t}}, c_{1}\right.$, $\left.k_{0}, k_{1}, F_{\mathrm{c}}, c, d\right)$ were investigated. Furthermore, we also assessed implications of deviating atmospheric deposition rates of mineral dust and $\mathrm{BC}$ on the mass balance as the ice core date is taken from another site (see Sect. 5.4). The parameters of the melt and accumulation model were not included in the sensitivity analysis because they were directly constrained by the continuous seasonal mass balance measurements at the study sites. The sensitivity of the parameters was assigned by varying each parameter by $5 \%$ intervals around to the chosen value in a range of $\pm 20 \%$, keeping all other parameters constant. Tab. 1 shows the used parameter ranges. According to
Table 1. Parameters of the impurity, the SSA and the snow density model and the corresponding parameter ranges $( \pm 20 \%)$ applied in the sensitivity analysis.

\begin{tabular}{|c|c|c|c|}
\hline Parameter & Unit & Value & Range \\
\hline \multicolumn{4}{|l|}{ Impurity model } \\
\hline Dust input & $\mu \mathrm{g} \mathrm{kg}^{-1}$ & 22.3 & $17.8-26.8$ \\
\hline BC input & $\mu \mathrm{g} \mathrm{kg}^{-1}$ & 23.2 & $18.6-27.8$ \\
\hline $\mathrm{BC}$ removal rate & $\%$ & 20 & $16-24$ \\
\hline $\mathrm{Fe}$ in $\mathrm{FeO}$ & $\%$ & 54.5 & $43.6-65.4$ \\
\hline $\mathrm{MAC} \mathrm{FeO} / \mathrm{BC}$ & - & 0.082 & $0.066-0.099$ \\
\hline \multicolumn{4}{|l|}{ SSA model } \\
\hline $\mathrm{SSA}_{\text {initial }}$ & $\mathrm{m}^{2} \mathrm{~kg}^{-1}$ & 73.0 & $58.4-87.6$ \\
\hline $\mathrm{SSA}_{\min }$ & $\mathrm{m}^{2} \mathrm{~kg}^{-1}$ & 8.0 & $6.4-9.6$ \\
\hline$C_{1}$ & $10^{-3} \mathrm{~mm}^{3} \mathrm{~d}^{-3}$ & 1.1 & $0.88-1.32$ \\
\hline$C_{2}$ & $10^{-5} \mathrm{~mm}^{3} \mathrm{~d}^{-3}$ & 3.7 & $2.96-4.44$ \\
\hline \multicolumn{4}{|c|}{ Snow density model } \\
\hline$a_{\mathrm{t}}$ & ${ }^{\circ} \mathrm{Cmm}^{-1}$ & 0.033 & $0.0264-0.0396$ \\
\hline$c_{1}$ & $\mathrm{~m}^{2} \mathrm{~h}^{-2} \mathrm{~kg}^{-1}$ & 0.001 & $0.0008-0.0012$ \\
\hline$k_{0}$ & $\mathrm{~m}^{3} \mathrm{~kg}^{-1}$ & 0.021 & $0.0168-0.0252$ \\
\hline$k_{1}$ & ${ }^{\circ} \mathrm{C}^{-1}$ & 0.08 & $0.064-0.096$ \\
\hline$F_{\mathrm{C}}$ & - & 0.02 & $0.016-0.096$ \\
\hline$c$ & $\mathrm{~m}^{-1} \mathrm{~h}^{-(\mathrm{d}-1)}$ & 1.0 & $0.8-1.2$ \\
\hline$d$ & - & 1.25 & $1.0-1.5$ \\
\hline
\end{tabular}

Anslow et al. (2008) we defined the sensitivity of a parameter as the slope around the origin of the curve, defined by the percentage change in the parameter value and the percentage change in the resulting model variable (mass balance in our case). For example a sensitivity of 0.5 designates that an arbitrary percentage change in the parameter value involves a half-as-large percentage change in the mass balance. A positive sensitivity means that an increase in the parameter value leads to an increase in the mass balance, a negative sensitivity that an increase in the parameter yields a decrease in mass balance.

Results of the sensitivity analysis are shown in Fig. 9. The mass balance was most sensitive to the amount of snow impurities and the parameters of the snow density model, while the parameters of the SSA model were clearly less relevant. In contrast to the input quantity of $\mathrm{BC}$, mineral dust had a less pronounced impact on modeled mass balance. A change of $10 \%$ in the $\mathrm{BC}$ concentration in precipitation led to a $5.8 \%$ change in mass balance, whereas the same change in the mineral dust concentration in precipitation only resulted in a $1.6 \%$ change in mass balance. The reason for this difference in sensitivity is the stronger absorption of solar radiation by $\mathrm{BC}$ compared to mineral dust. An even higher sensitivity could be assigned to the removal efficiency of $\mathrm{BC}$ with melt water. A $10 \%$ change in the $\mathrm{BC}$ removal rate leads to a 1.5 times larger change in the mass balance. This is partic- 


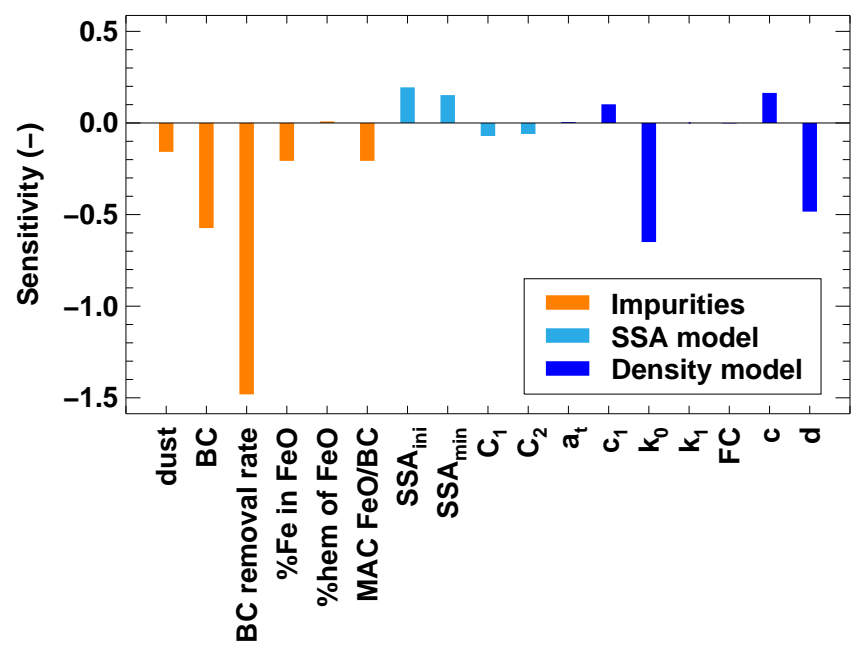

Figure 9. Sensitivity of annual surface mass balance (i.e., the percentage change in the parameter value vs. the percentage change in annual mass balance) to the different parameters of the impurity, the specific surface area and the snow density model, as well as the sensitivity to the input of mineral dust and BC.

ularly important since the removal rates are subject to considerable uncertainty (see Sect. 5.5). Hence, the removal of $\mathrm{BC}$ by melt water seems to be the most critical point of the simulation and strongly controls the impact of $\mathrm{BC}$ on the long-term glacier mass balance. Besides the impurity model, also the performance of the density model affected the simulations. In particular, parameter $k_{0}$ (Eq. 11), describing the density change due to compaction, and the outflow parameter $d$ (Eq. 10) were found to have sensitivities that are comparable to those of the input concentration of BC (Fig. 9). The higher the values of the density parameters, $k_{0}$ and $d$, the faster is snow compaction. More efficient compaction in turn entails higher impurity concentrations in the surface snow layer and thus enhanced melt rates. The parameters of the SSA model show the lowest sensitivity and therefore are less relevant for the results. The two parameters, $\mathrm{SSA}_{\min }$ and $\mathrm{SSA}_{\text {initial }}$ (Eq. 5), are the most sensitive ones. An increase in the two parameter values leads to a depletion in pure snow albedo, which slightly diminishes the impact on snow impurities. However, this effect is small compared to the other uncertainties.

\subsection{Spatial distribution of the effect of light-absorbing impurities}

The extent of the impact of Saharan dust and BC on the glacier mass balance is spatially variable and strongly depends on prevailing conditions. According to our results, the effect of light-absorbing impurities increase from the accumulation area towards the equilibrium line as higher melt rates lead to a re-exposure of old firn layers bearing lightabsorbing impurities. In the ablation area where most glacier mass loss occurs, however, the processes are different. Winter accumulation is not preserved over multiple years and thus light-absorbing snow impurities affect only the albedo of the winter snow cover until it has been melted away. During the summer season when bare ice is exposed at the surface, snow impurities are removed by melt water which might limit the impact of impurities on glacier melt, although a darkening on gently sloping glacier tongues has also been observed (Oerlemans et al., 2009). Hence, we suppose that the effect of Saharan dust and BC in the ablation area is lower compared to areas near the equilibrium line.

\subsection{Transferring mineral dust/black carbon to Claridenfirn}

Our analysis is based on the general assumption that concentrations of Saharan dust and BC in precipitation at Colle Gnifetti and Fiescherhorn (Fig. 1) are comparable to those at Claridenfirn. In order to receive undisturbed records of past aerosol concentrations, only few sites in the Alpine region are suitable. Prerequisites are high elevation to exclude chemical disturbance by melt water percolation, sufficient ice thickness to ensure long enough records and flat terrain to limit the effect of ice flow (Wagenbach and Geis, 1989). For this reason, we relied on time series at locations other than Claridenfirn and had to transpose the measurements to the study site for which long-term mass balance measurements were available.

In the 1990s a large-scale study about the chemical composition of high-alpine winter snow packs was carried out in the Alps with the aim of detecting the regional and altitudinal distribution of major ions (SNOSP; Nickus et al., 1997). It was found that the concentration of most ionic species in winter snow increases by about one-third from west to east and that ionic loads show no regional preference due to opposite gradients in the prevailing precipitation patterns. The same also applies to variations with altitude: at higher elevation, ion concentrations are lower compared to valleys, but the general increase in precipitation with elevation compensates for this effect, so that ionic loads are expected to be in the same order of magnitude independent of absolute elevation. A more detailed investigation of selected sampling locations in the vicinity of Colle Gnifetti/Fiescherhorn (Breithorn, Gorner-/Theodulgletscher, Colle Vincent, Jungfraujoch) revealed that there is no distinct altitudinal trend in ionic loads (Nickus et al., 1997). A recent study about atmospheric deposition in alpine and subalpine areas confirms these results and concludes that there are no clear regional gradients, but a significant spatial variability of atmospheric ion deposition over the Alps (Rogora et al., 2006). Another study concluded that sites with large quantities of precipitation exhibit highest ion concentrations because they receive generally the first, more contaminated fraction of a precipitation event (Nickus et al., 1998). 
The above mentioned studies are mainly focused on anthropogenic impurities of winter snow packs and can not be directly transferred to the situation at Claridenfirn. We suppose that concentrations at Claridenfirn might be higher than at Colle Gnifetti/Fiescherhorn due to (1) its eastern location, (2) the lower elevation and thus proximity to the polluted mixing layer, and (3) the higher precipitation rates (MeteoSwiss, 2014b). However, we are unable to conclude with certainty whether and to what extent ion concentrations differ between the ice cores and our study site. For these reasons we adopted the impurity concentrations measured at Colle Gnifetti/Fiescherhorn directly to the study site without a transfer function. Our assumption is supported by a supplementary analysis carried out on Claridenfirn. Kappenberger and Steingruber (2014) collected and analyzed winter snow samples for major ions between 1995 and 2013. Comparison of bulk winter snow concentrations with those at Colle Gnifetti revealed that concentrations at both locations are in the same order of magnitude. In contrast to Saharan dust, which is transported by large-scale upper air flows, BC concentrations are more influenced by the regional environment. Therefore, the assumption of using concentrations from a remote location might be less valid for BC than for Saharan dust. Actual $\mathrm{BC}$ input concentrations are thus subject to a higher uncertainty.

\subsection{Removal by melt water}

When a snowpack begins to melt, the insoluble snow impurities are partly retained and concentration of impurities in the surface snow increases as snow melt proceeds, thus reducing snow albedo. Consequently, melt is amplified and therefore provides a positive feedback on radiative forcing by light-absorbing impurities. To what extent snow impurities are removed by melt water percolation has not been fully clarified and only a small number of studies has addressed this issue so far. Important contribution is made by Conway et al. (1996), who found that particles of volcanic ash remained at or near the surface throughout the melting process, while a large part of soot particles was flushed through the snow with the melt water. They suppose that the difference in the particle's diameters is responsible for the different behavior of ash and soot during the melting process. Doherty et al. (2013) concluded that removal rates due to melt water percolation of BC are in the order of 10-30\% which is in agreement with the results by Conway et al. (1996). Based on the limited information available, a removal efficiency of $20 \%$ for BC seems to be a reasonable assumption. The sensitivity study indicated that the results are more sensitive on the removal rate than the amount of mineral dust and $\mathrm{BC}$ input. Hence, this issue needs further investigation. However, ignoring flushing-out of $\mathrm{BC}$ with melt would lead to an overestimation of surface concentrations and thus to an excessive melt amplification through BC (Doherty et al., 2013).

\subsection{Mass balance model}

The performance of the albedo parameterization mainly depends on an accurate modeling of the specific surface area of snow grains and the fraction of snow impurities in the surface snow. Roy et al. (2013) demonstrate that the simulated snow grain sizes are in good agreement with measurements and that despite the simplicity of the SSA model results are comparable to well-established snow models (i.e., Crocus, Brun et al., 1989, 1992). The root-mean-square error in the overall SSA is $8.0 \mathrm{~m}^{2} \mathrm{~kg}^{-1}$ and corresponding to an albedo uncertainty in the order of $\pm 3 \%$ for small grains and of $\pm 6 \%$ for large grains. The main limitation of the SSA model is the performance during wet conditions due to the simplification regarding the 1-layer model for liquid water. As for the SSA model, the liquid water content is important also for the snow density model (De Michele et al., 2013). Snow density measurements, performed twice a year during the winter and late summer surveys on Claridenfirn, were used to validate the snow density model. Correlation of observed and simulated snow densities reveals a $r^{2}$ of 0.52 and 0.47 . Mean absolute differences are 10.8 and $9.4 \mathrm{~kg} \mathrm{~m}^{-3}$ (corresponding to a relative difference of $\sim 2 \%$ ) for the lower and upper measurement site, respectively. This indicates that the density model well captures the typical snow density, but does not fully reproduce interannual variability.

\section{Conclusions}

In this study we analyzed the impact of Saharan dust and black carbon on the mass balance of an Alpine glacier over a centennial period (1914-2014) covered by exceptional observational data sets. A mass balance model including a parameterization for albedo was combined with a snow density model in order to track snow layers and impurities over time. The combined model was forced with temperature and precipitation time series in daily resolution, the latter being assigned by mineral dust and $\mathrm{BC}$ concentrations retrieved from ice/firn cores.

On average the presence of Saharan dust at the glacier surface reduced mean annual albedo by less than 0.01 . The associated decrease in the mean annual mass balance was 28-58 $\mathrm{mm}$ w.e. depending on the location on the glacier (accumulation area, equilibrium line). However, in individual years with very high supply of Saharan dust, surface albedo can be reduced substantially with a strong impact on snow and ice ablation. In addition to years with large atmospheric dust deposition, periods of strong melting may lead to significantly enhanced dust concentrations due to re-exposure of buried firn layers with a high impurity content. In contrast to mineral dust, BC affected the mass balance more efficiently and clearly dominated light absorption in snow, except for years with large Saharan dust events. On average BC lowered the annual albedo by 0.03 and reduced the mean annual mass 
balance by $183-301 \mathrm{~mm}$ w.e. Due to the combined effect of $\mathrm{BC}$ and Saharan dust, annual ablation on Claridenfirn was increased by $15-19 \%$ on average over 1914-2014 compared to pure snow conditions. In the accumulation area, the impact of Saharan dust and BC on the mass balance was clearly less pronounced due to the prevailing positive mass balances that tend to continuously bury snow impurities. The most sensitive parameter of our assessment is the removal rate of snow impurities by melt water, a process which is until now only poorly understood.

Our study demonstrates that the influence of snow impurities on glacier melting should be taken into consideration, when modeling the mass balance of alpine glaciers over longterm periods in order to increase the reliability of the simulations. Particularly in years with large deposition of Saharan dust or $\mathrm{BC}$ and during periods with negative glacier mass balance, re-exposure of old firn layers can importantly impact on the rate of snow and ice ablation and thus enhance the albedo feedback. Furthermore, the study emphasizes the crucial role of $\mathrm{BC}$ in melt processes taking place on Alpine glaciers.

Acknowledgements. This study was supported by the National Research Programme NRP61. Many thanks go to all those who performed mass balance measurements at Claridenfirn with great effort and care. We particularly thank the two key players, H. Müller and G. Kappenberger, for collecting and homogenizing the mass balance measurements. T. M. Jenk and M. Sigl are gratefully acknowledged for providing ice core data of Colle Gnifetti and Fiescherhorn. The analysis of EC in the upper part of the Fiescherhorn ice core (1940-2002) was funded by the EU FP7 project PEGASOS. We thank M. Funk for his helpful comments on an earlier version of the manuscript. Comments by two anonymous reviewers were helpful to finalize the manuscript. Furthermore, we thank MeteoSwiss for providing meteorological time series and the Global Energy Balance Archive (GEBA), ETH Zurich, for the radiation data of Davos. Aerosol measurements at the high-alpine research station Jungfraujoch were conducted by Global Atmosphere Watch (GAW).

Edited by: V. Radic

\section{References}

Alfaro, S., Lafon, S., Rajot, J., Formenti, P., Gaudichet, A., and Maillé, M.: Iron oxides and light absorption by pure desert dust: an experimental study, J. Geophys. Res., 109, D08208, doi:10.1029/2003JD004374, 2004.

Anderson, E.: A point energy and mass balance model of a snow cover, NOAA Tech. Rep. NWS 19, NOAA, US Dept. Commer., Washington, DC, 150 pp., 1976.

Anslow, F., Hostetler, S., Bidlake, W., and Clark, P.: Distributed energy balance modeling of South Cascade Glacier, Washington and assessment of model uncertainty, J. Geophys. Res., 113, F02019, doi:10.1029/2007JF000850, 2008.
Begert, M., Schlegel, T., and Krichhofer, W.: Homogeneous temperature and precipitation series of Switzerland from 1864 to 2000 , Int. J. Climatol., 25, 65-80, 2005.

Bond, T., Bhardwaj, E., Dong, R., Jogani, R., Jung, S., Roden, C., Streets, D., and Trautmann, N.: Historical emissions of black and organic carbon aerosol from energy-related combustion, 1850-2000, Global Biogeochem. Cy., 21, GB2018, doi:10.1029/2006GB002840, 2007.

Bond, T., Doherty, S., Fahey, D., Forster, P., Berntsen, T., DeAngelo, B., Flanner, M., Ghan, S., Kärcher, B., Koch, D., Kinne, S., Kondo, Y., Quinn, P., Sarofim, M., Schultz, M., Schulz, M., Venkataraman, C., Zhang, H., Zhang, S., Bellouin, N., Guttikunda, S., Hopke, P., Jacobson, M., Kaiser, J., Klimont, Z., Lohmann, U., Schwarz, J., Shindell, D., Storelvmo, T., Warren, S., and Zender, C.: Bounding the role of black carbon in the climate system: a scientific assessment, J. Geophys. Res., 118, 5380-5552, 2013.

Brun, E.: Investigation on wet-snow metamorphism in respect of liquid-water content, Ann. Glaciol., 13, 22-26, 1989.

Brun, E., Martin, E., Simon, V., Gendre, C., and Coleou, C.: An energy and mass model of snow cover suitable for operational avalanche forecasting, J. Glaciol., 35, 333-342, 1989.

Brun, E., David, P., Sudul, M., and Brunot, G.: A numerical model to simulate snow-cover stratigraphy for operational avalanche forecasting, J. Glaciol., 38, 13-22, 1992.

Collaud Coen, M., Weingartner, E., Schaub, D., Hueglin, C., Corrigan, C., Henning, S., Schwikowski, M., and Baltensperger, U.: Saharan dust events at the Jungfraujoch: detection by wavelength dependence of the single scattering albedo and first climatology analysis, Atmos. Chem. Phys., 4, 2465-2480, doi:10.5194/acp4-2465-2004, 2004.

Conway, H., Gades, A., and Raymond, C.: Albedo of dirty snow during conditions of melt, Water Resour. Res., 32, 1713-1718, 1996.

Corripio, J.: Vectorial albegra algorithms for calculating terrain parameters from DEMs and solar radiation modelling in mountainous terrain, Int. J. Geogr. Inf. Sci., 17, 1-23, 2003.

De Michele, C., Avanzi, F., Ghezzi, A., and Jommi, C.: Investigating the dynamics of bulk snow density in dry and wet conditions using a one-dimensional model, The Cryosphere, 7, 433-444, doi:10.5194/tc-7-433-2013, 2013.

Doherty, S., Grenfell, T., S, F., Hegg, D., Brandt, R., and Warren, S.: Observed vertical redistribution of black carbon and other insoluble light-absorbing particles in melting snow, J. Geophys. Res., 118, 5553-5569, 2013.

Domine, F., Taillandier, A.-S., and Simpson, W.: A parameterization of the specific surface area of seasonal snow for field use and for models of snowpack evolution, J. Geophys. Res., 112, F02031, doi:10.1029/2006JF000512, 2007.

Eichler, A., Schwikowski, M., Gäggeler, H., Furrer, V., Synal, H., Beer, J., Saurer, M., and Funk, M.: Glaciochemical dating of an ice core from the upper Grenzgletscher (4200 ma.s.1.), J. Glaciol., 46, 507-515, 2000.

Flanner, M. G., Zender, C., Randerson, J., and Rasch, P.: Presentday climate forcing and response from black carbon in snow, J. Geophys. Res., 112, D11202, doi:10.1029/2006JD008003, 2007.

Flanner, M. G., Zender, C. S., Hess, P. G., Mahowald, N. M., Painter, T. H., Ramanathan, V., and Rasch, P. J.: Springtime warming and reduced snow cover from carbonaceous particles, 
Atmos. Chem. Phys., 9, 2481-2497, doi:10.5194/acp-9-24812009, 2009.

Gabbi, J., Carenzo, M., Pellicciotti, F., Bauder, A., and Funk, M.: A comparison of empirical and physically based glacier surface melt models for long-term simulations of glacier response, J. Glaciol., 60, 1140-1154, 2014.

Gardner, A. and Sharp, M.: A review of snow and ice albedo and the development of a new physically based broadband albedo parameterization, J. Geophys. Res., 115, F01009, doi:10.1029/2009JF001444, 2010.

Ginot, P., Dumont, M., Lim, S., Patris, N., Taupin, J.-D., Wagnon, P., Gilbert, A., Arnaud, Y., Marinoni, A., Bonasoni, P., and Laj, P.: A 10 year record of black carbon and dust from a Mera Peak ice core (Nepal): variability and potential impact on melting of Himalayan glaciers, The Cryosphere, 8, 1479-1496, doi:10.5194/tc-8-1479-2014, 2014.

Huss, M. and Bauder, A.: 20th-century climate change inferred from four long-term point observations of seasonal mass balance, Ann. Glaciol., 50, 207-214, 2009.

Huss, M., Funk, M., and Ohmura, A.: Strong Alpine glacier melt in the 1940s due to enhanced solar radiation, Geophys. Res. Lett., 36, L23501, doi:10.1029/2009GL040789, 2009.

IPCC: Climate Change 2013, The Physical Scientific Basis, Contributions of Working Group I to the Fifth Assessment Report of the Intergovernmental Panel on Climate Change, edited by: Stocker, T. F., Qin, D., Plattner, G.-K., Tignor, M., Allen, S. K., Boschung, J., Nauels, A., Xia, Y., Bex V., and Midgley, P. M., Cambridge University Press, Cambridge, UK and New York, NY, USA, 2013.

Iqbal, M.: An Introduction to Solar Radiation, Academic Press, London, 1983.

Jenk, T. M., Szidat, S., Schwikowski, M., Gäggeler, H. W., Brütsch, S., Wacker, L., Synal, H.-A., and Saurer, M.: Radiocarbon analysis in an Alpine ice core: record of anthropogenic and biogenic contributions to carbonaceous aerosols in the past (1650-1940), Atmos. Chem. Phys., 6, 5381-5390, doi:10.5194/acp-6-5381-2006, 2006.

Jenk, T. M., Szidat, S., Bolius, D., Sigl, M., Gäggeler, H. W., Wacker, L., Ruff, M., Barbante, C., Boutron, C. F., and Schwikowski, M.: A novel radiocarbon dating technique applied to an ice core from the Alps indicating late Pleistocene ages, J. Geophys. Res., 114, D14305, doi:10.1029/2009JD011860, 2009.

Kappenberger, G. and Steingruber, S.: Analisi chimica del manto nevoso sui ghiacciai Basodino e Clariden nel periodo 19922014, Tech. rep., Ufficio protezione aria, Sezione protezione aria, acqua e suolo, Dipartimento del territorio, Bellizona, Switzerland, 2014.

Kaspari, S., Painter, T. H., Gysel, M., Skiles, S. M., and Schwikowski, M.: Seasonal and elevational variations of black carbon and dust in snow and ice in the Solu-Khumbu, Nepal and estimated radiative forcings, Atmos. Chem. Phys., 14, 80898103, doi:10.5194/acp-14-8089-2014, 2014.

Kelleners, T., Chandler, D., McNamara, J., Gribb, M., and Seyfried, M.: Modelling the water and energy balance of vegetated areas with snow accumulation, Vadose Zone J., 8, 10131030, 2009.

Koch, D.: Transport and direct radiative forcing of carbonaceous and sulfate aerosols in the GISS GCM, J. Geophys. Res., 106, 20311-20332, 2001.
Kojima, K.: Densification fo seasonal snow cover, in: Proc. Internat. Conf. Physics Snow Ice, Hokkaido University, Sapporo, Japan, 929-952, 1967.

Kondo, J. and Yamazaki, T.: A prediction model for snowmelt, snow surface temperature and freezing depth using a heat balance method, J. Appl. Meteorol., 29, 375-384, 1990.

Kongoli, C. and Bland, W.: Long-term snow depth simulations using a modified atmosphere-land exchange model, Agr. Forest Meteorol., 104, 273-287, 2000.

Kopacz, M., Mauzerall, D. L., Wang, J., Leibensperger, E. M., Henze, D. K., and Singh, K.: Origin and radiative forcing of black carbon transported to the Himalayas and Tibetan Plateau, Atmos. Chem. Phys., 11, 2837-2852, doi:10.5194/acp-11-28372011, 2011.

Lafon, S., Rajot, J., Alfaro, S., and Gaudichet, A.: Quantification of iron oxides in desert aerosol, Atmos. Environ., 38, 1211-1218, 2004.

Lafon, S., Sokolik, I., Rajot, J., Caquineau, S., and Gaudichet, A.: Characterization of iron oxides in mineral dust aerosols: Implications for light absorption, J. Geophys. Res., 111, D21207, doi:10.1029/2005JD007016, 2006.

Lavanchy, V., Gäggeler, H., Schotterer, U., Schwikowski, M., and Baltensperger, U.: Historical record of carbonaceous particle concentrations from a European high-alpine glacier (Colle Gnifetti, Switzerland), J. Geophys. Res., 104, 21227-21236, 1999.

Mellor, M.: A review of basic snow mechanics, in: Snow Mechanics: Proceedings of the Grindelwald (International) Symposium, vol. 114, International Association of Hydrological Sciences, Grindelwald, Switzerland, 251-291, 1975.

MeteoSwiss: Detection of Saharan dust event at the Jungfraujoch, available at: http://www.meteoschweiz.admin.ch/ web/en/climate/observation_systems/upperair_observations/ saharan-dust-event.html (last access: 13 October 2014), 2014a.

MeteoSwiss: Norm values - maps, available at: http: //www.meteoschweiz.admin.ch/web/en/climate/swiss_climate/ Klimakarten_schweiz_1961-90.html (last access: 17 September 2014), 2014b.

Müller, H. and Kappenberger, G.: Claridenfirn-Messungen, 1914-1984: Daten und Ergebnisse eines gemeinschaftlichen Forschungsprojektes, Zürcher Geographische Schriften, vol. 40, Verlag der Fachvereine, Zürich, 79 pp., 1991.

Nickus, U., Kuhn, M., Baltensperger, U., Delmas, R., Gäggeler, H., Kasper, A., Kromp-Kolb, H., Maupetit, F., Novo, A., Pichlmayer, F., Preunkert, S., Puxbaum, H., Rossi, G., Schöner, W., Schwikowski, M., Seibert, P., Staudinger, M., Trockner, V., Wagenbach, D., and Winiwarter, W.: SNOSP: ion deposition and concentration in high alpine snow packs, Tellus B, 49, 56-71, 1997.

Nickus, U., Kuhn, M., Novo, A., and Rossi, G.: Major element chemistry in alpine snow along a north-south transect in the Eastern Alps, Atmos. Environ., 32, 4053-4060, 1998.

Nomura, M.: Studies on the delay mechanism of runoff to snowmelt, Contributions from the Institute of Low Temperature Science, Hokkaido University, 39, 1-49, 1994.

Oerlemans, J., Giesen, R., and van den Broeken, M.: Retreating alpine glaciers: increased melt rates due to accumulation of dust (Vadret da Morteratsch, Switzerland), J. Glaciol., 55, 729-736, 2009. 
Ohara, N. and Kavvas, M.: Field observations and numerical model experiments for the snowmelt process at a field site, Adv. Water Resour., 29, 194-211, 2006.

Ohmura, A., Gilgen, H., and Wild, M.: Global Energy Balance Archive (GEBA), World Climate Program - Water Project A7, Report 1: Introduction, Zürcher Geographische Schriften, vol. 34, Verlag der Fachvereine, Zürich, 62 pp., 1989.

Painter, T., Barrett, A., Landry, C., Neff, J., Cassidy, M., Lawrence, C., McBride, K., and Farmer, G. L.: Impact of disturbed desert soils on duration of mountain snow cover, Geophys. Res. Lett., 34, L12502, doi:10.1029/2007GL030284, 2007.

Painter, T., Deems, J., Belnap, J., Hamlet, A., Landry, C., and Udall, B.: Response of Colorado River runoff to dust radiative forcing in snow, P. Natl. Acad. Sci. USA, 10, 6603-6615, 2010.

Painter, T., Flanner, M. G., Kaser, G., Marzeion, B., VanCuren, R. A., and Abdalati, W.: End of the Little Ice Age in the Alps forced by industrial black carbon, P. Natl. Acad. Sci. USA, 110, 15216-15221, 2013.

Pellicciotti, F., Brock, B., Strasser, U., Burlando, P., Funk, M., and Corripio, J.: An enhanced temperature-index glacier melt model including the shortwave radiation balance: development and testing for Haut Glacier d'Arolla, Switzerland, J. Glaciol., 51, 573587, 2005.

Pellicciotti, F., Raschle, T., Huerlimann, T., Carenzo, M., and Burlando, P.: Transmission of solar radiation through clouds on melting glaciers: a comparison of parameterizations and their impact on melt modelling, J. Glaciol., 57, 202, doi:10.3189/002214311796406013, 2011.

Prodi, F. and Fea, G.: A case of transport and deposition of Saharan dust over the Italian Peninsula and southern Europe, J. Geophys. Res., 84, 6951-6960, 1979.

Qian, Y., Flanner, M. G., Leung, L. R., and Wang, W.: Sensitivity studies on the impacts of Tibetan Plateau snowpack pollution on the Asian hydrological cycle and monsoon climate, Atmos. Chem. Phys., 11, 1929-1948, doi:10.5194/acp-11-19292011, 2011.

Raes, F., Dingenen, R. V., Vignati, E., Wilson, J., Putaud, J., Seinfeld, J. H., and Adams, P.: Formation and cycling of aerosols in the global troposphere, Atmos. Environ., 34, 4215-4240, 2000.

Ramanathan, V. and Carmichael, G.: Global and regional climate changes due to black carbon, Nat. Geosci., 1, 221-227, 2008.

Rogora, M., Mosello, R., Arisci, S., Brizzio, M., Barbieri, A., Balestrini, R., Waldner, P., Schmitt, M., Stähli, M., Thimonier, A., Kalina, M., Puxbaum, H., Nickus, U., Ulrich, E., and Probst, A.: An overview of atmospheric deposition chemistry over the Alps: present status and long-term trends, Hydrobiologia, 562, 17-40, 2006.

Roy, A., Royer, A., Montpetit, B., Bartlett, P. A., and Langlois, A.: Snow specific surface area simulation using the one-layer snow model in the Canadian LAnd Surface Scheme (CLASS), The Cryosphere, 7, 961-975, doi:10.5194/tc-7-961-2013, 2013.

Schwikowski, M., Seibert, P., Baltensperger, U., and Gäggeler, H.: A study of an outstanding Saharan dust event at the high-alpine site Jungfraujoch, Switzerland, Atmos. Environ., 29, 1829-1842, 1995.
Shi, Z., Krom, M., Bonneville, S., Baker, A., Bristow, C., Drake, N., Mann, G., Carslaw, K., McQuaid, J., Jickells, T., and Benning, L.: Influence of chemical weathering and aging of iron oxides on the potential iron solubility of Saharan dust during simulated atmospheric processing, Global Biogeochem. Cy., 25, GB2010, doi:10.1029/2010GB003837, 2011.

Sigl, M.: Ice core based reconstruction of past climate conditions from Colle Gnifetti, Swiss Alps, PhD thesis, Universitiy of Bern, Bern, 2009.

Singh, V.: Kinematic wave modelling in water resources: a historical perspective, Hydrol. Process., 15, 671-706, 2001.

Skiles, S., Painter, T., Deems, J., Bryant, A. C., and Landry, C.: Dust radiative forcing in snow of the Upper Colorado River Basin: 2. Interannual variability in radiative forcing and snowmelt rates, Water Resour. Res., 48, W07522, doi:10.1029/2012WR011986, 2012.

SMA-Annalen: Annalen der Schweizerischen Meteorologischen Anstalt, Zürich, 1864-2014.

Sokolik, I. and Toon, O.: Incorporation of mineralogical composition into models of the radiative properties of mineral aerosol from UV to IR wavelengths, J. Geophys. Res., 104, 9423-9444, 1999.

Sterle, K. M., McConnell, J. R., Dozier, J., Edwards, R., and Flanner, M. G.: Retention and radiative forcing of black carbon in eastern Sierra Nevada snow, The Cryosphere, 7, 365-374, doi:10.5194/tc-7-365-2013, 2013.

Taillandier, A.-S., Domine, F., Simpson, W., Sturm, M., and Douglas, T.: Rate of decrease of the specific surface area of dry snow: Isothermal and temperature gradient conditions, J. Geophys. Res., 112, F03003, doi:10.1029/2006JF000514, 2007.

Tarboton, D. and Luce, C.: Utah energy balance snow accumulation and melt model (UEB): computer model technical description and users guide, Tech. rep., Utah Water Resources Laboratory, Logan, 1996.

Wagenbach, D. and Geis, K.: The mineral dust record in a high altitude Alpine glacier (Colle Gnifetti, Swiss Alps), in: Paleoclimatology and Paleometeorology: Modern and Past Patterns of Global Atmospheric Transport, edited by: Leinen, M. and Sarnthein, M., vol. 282, Springer, the Netherlands, 543-564, 1989.

Wagenbach, D., Preunkert, S., Schäfer, J., Jung, W., and Tomadin, L.: Northward transport of Saharan dust recorded in a deep alpine ice core, in: The Impact of Desert Dust Across the Mediterranean, edited by: Guerzoni, S. and Chester, R., Environmental Science and Technology Library, vol. 11, Springer, the Netherlands, 291-300, 1996.

Warren, S.: Impurities in snow: effects on albedo and snowmelt (review), Ann. Glaciol., 5, 177-179, 1984.

Zhang, Y., Wang, S., Barr, A., and Black, T.: Impact of snow cover on soil temperature and its simulation in a boreal aspen forest, Cold Reg. Sci. Technol., 52, 355-370, 2008. 